Interactive comment on "Aerosol-Cloud Closure Study on Cloud Optical Properties using Remotely Piloted Aircraft Measurements during a BACCHUS Field Campaign in Cyprus" by Radiance Calmer et al.

\title{
Radiance Calmer et al.
}

radiance.calmer@gmail.com

Received and published: 15 August 2019

The comment was uploaded in the form of a supplement:

https://www.atmos-chem-phys-discuss.net/acp-2019-8/acp-2019-8-AC1-

supplement.pdf 